\title{
Impact of surfactants on the biotransformation of methyl ricinoleate into $\gamma$-decalactone by Yarrowia lipolytica
}

\author{
Mario Aguedo ${ }^{1}$, Yves Waché*, Florence Coste, Florence Husson, Jean-Marc Belin \\ Laboratoire de Microbiologie, UMR UB-INRA 1232, ENSBANA, 1, Esplanade Erasme, 21000 Dijon, France
}

Received 3 July 2003; received in revised form 31 October 2003; accepted 25 November 2003

Available online 09 April 2004

\begin{abstract}
Surfactants play a key role in the biotechnological degradation of hydrophobic substrates, however this role is often misunderstood. During the biotransformation of methyl ricinoleate into the aroma compound $\gamma$-decalactone by the yeast Yarrowia lipolytica, a direct contact occurs between the surface of the cells and the small droplets of substrate. The impact of a series of surfactants on this process was investigated. Both ionic surfactants tested were toxic towards the yeast. This effect may be linked to a decrease in the cell membrane integrity. The interfacial area of the emulsion varied according to the non-ionic surfactant used, and this factor was correlated with the productivity of the biotransformation. By evaluating the effect of surfactants on the capacity of the cells to adhere to decane (MATH test), it was shown that the adhesion of methyl ricinoleate on yeast surface is not a rate-limiting point for the process.
\end{abstract}

(C) 2004 Elsevier B.V. All rights reserved.

Keywords: Emulsion; Surfactants; Yeast cells; $\gamma$-Decalactone

\section{Introduction}

The yeast Yarrowia lipolytica is particularly adapted to hydrophobic substrates. It is often isolated from oily media and used in many processes such as lipase production $[1,2]$, decontamination of diesel-contaminated soils [3] and olive-mill waste waters [4], production of proteins on alkanes [5] and of aroma compounds [6,7]. In most of these cases, the substrate is presented to the yeast as an emulsion.

Using mainly bacterial models, some authors have tried to characterise the biphasic media and investigated the microbial growth kinetics in such conditions [8-12]. Due to the limited solubility of these hydrophobic substrates in water, growth occurs directly on fatty droplets in most of the cases [13] and the uptake can be directly interfacial or surfactant mediated $[14,15]$. Some authors have observed surface structures which might be involved in the uptake [16,17], structures which might also have an impact on the surface

\footnotetext{
* Corresponding author. Tel.: +33-3-8039-6680; fax: +33-3-8039-6641.

E-mail address: ywache@u-bourgogne.fr (Y. Waché).

${ }^{1}$ Present address: Dept de Engenheria Biológica, Universidade do Minho, Campus de Gualtar, 4710-057 Braga, Portugal.
}

properties of the microorganisms and thus on the adhesion of fatty globules $[15,18,19]$.

Biphasic media are also used in the biotransformation of methyl ricinoleate (a hydroxylated C18-fatty acid methyl ester) into $\gamma$-decalactone, a fruity and creamy aroma compound, by the yeast $Y$. lipolytica (Fig. 1). Many works have dealt with the biotransformation pathway which involves the primary metabolism of $\beta$-oxidation (these works are reviewed in [6]). The different steps are now quite well known and recent results highlight the impact of environmental conditions on the biotransformation and on the regulation of $\beta$-oxidation fluxes [20]. In such a reaction, the interfacial area between the organic and aqueous phases is important not only to favour the access of yeast to substrate but also to extract the produced lactone. It is indeed important to subtract it from the degradation by yeast cells and also to avoid the contact of this compound with cell membranes, contact which can decrease the yields by perturbing the cell integrity [21]. Contrasting with other studies reporting the production of surface-active compounds by $Y$. lipolytica strains $[22,23]$, we have observed no biosurfactant production in the conditions we used for biotransformation but the present strain exhibits surface-active properties [24] resulting in adhesion to methyl ricinoleate droplets [25]. In this study, we 


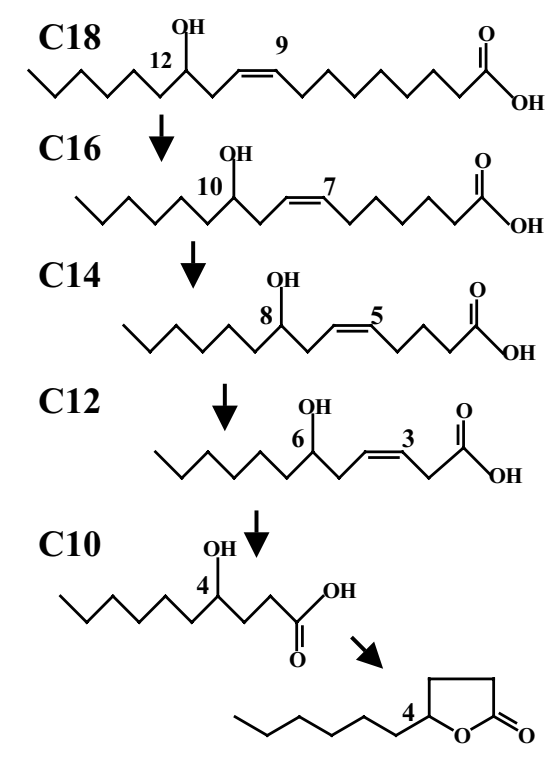

Fig. 1. Fatty acids observed as intermediates in the biotransformation of ricinoleic acid (18 carbons: C18) into $\gamma$-decalactone (10 carbons: $\mathrm{C} 10)$.

investigated the impact of surfactants on the biotransformation. Some of the compounds we tested were toxic towards yeast cells but the surfactants could also modify the yeast surface hydrophobicity and the mean lipid globules size, resulting in an important impact on $\gamma$-decalactone production.

\section{Experimental}

\subsection{Strains, media and culture conditions}

Unless otherwise stated, products were from SigmaAldrich (St-Quentin Fallavier, France). The Y. lipolytica W29 (ATCC20460; CLIB89) strain was used in this study. It was grown at $27^{\circ} \mathrm{C}$ in $500 \mathrm{ml}$ baffled Erlenmeyer flasks containing $200 \mathrm{ml}$ medium and agitated at $140 \mathrm{rpm}$. After inoculation with $5 \times 10^{6} \mathrm{cells} / \mathrm{ml}$, the preculture was carried out in a $\mathrm{pH} 5.6$ adjusted-glucose medium containing per litre: $15 \mathrm{~g}$ glucose, $2.5 \mathrm{~g} \mathrm{NH} 4 \mathrm{Cl}, 2.1 \mathrm{~g} \mathrm{KH}_{2} \mathrm{PO}_{4}, 3.6 \mathrm{~g}$ $\mathrm{Na}_{2} \mathrm{HPO}_{4}, 0.2 \mathrm{~g} \mathrm{MgSO}_{4} \cdot 7 \mathrm{H}_{2} \mathrm{O}, 0.1 \mathrm{~g} \mathrm{NaCl}, 0.005 \mathrm{~g} \mathrm{FeSO}_{4}$, $0.001 \mathrm{~g} \mathrm{CuSO}_{4}, 5 \times 10^{-4} \mathrm{~g} \mathrm{ZnCl}_{2}$ and $0.1 \mathrm{~g}$ yeast extract. Cells in late log-phase $(19 \mathrm{~h})$ were then washed $(6000 \mathrm{~g}$, $5 \mathrm{~min}$ ) three times in $0.9 \mathrm{~g} / \mathrm{l} \mathrm{NaCl}$ and transferred to the biotransformation medium at an initial concentration of $10^{8}$ cells $/ \mathrm{ml}$. This medium was composed of $10 \mathrm{~g} / \mathrm{l}$ methyl ricinoleate (Stéarinerie Dubois, Boulogne, France), $2.5 \mathrm{~g} / \mathrm{l}$ $\mathrm{NH}_{4} \mathrm{Cl}, 6.7 \mathrm{~g} / \mathrm{l}$ Yeast Nitrogen Base (YNB) and a surfactant at the specified concentration.

\subsection{Extraction and analysis}

For extraction and analysis, $2 \mathrm{ml}$ samples were removed and extracted with $2 \mathrm{ml}$ diethyl ether by 10 gentle shakings after addition of $\gamma$-undecalactone (internal standard). After $30 \mathrm{~min}$, the ether phase was analysed in a HP6890 gas chromatograph (Agilent Technologies, Lyon, France) with a HP-INNOWax capillary column (Agilent) $(30 \mathrm{~m} \times 320 \mu \mathrm{m} \times$ $0.25 \mu \mathrm{m}$ ) with $\mathrm{N}_{2}$ as a carrier gas at a linear flow rate of $4.3 \mathrm{ml} / \mathrm{min}$. The split injector (split ratio, 7.1:1) temperature was set to $250^{\circ} \mathrm{C}$ and that of the FID detector to $300^{\circ} \mathrm{C}$. The oven temperature was programmed to increase from 60 to $145^{\circ} \mathrm{C}$ at a rate of $5^{\circ} \mathrm{C} / \mathrm{min}$ and then at a rate of $2{ }^{\circ} \mathrm{C} / \mathrm{min}$ to $215^{\circ} \mathrm{C}$.

\subsection{Yeast viability}

Yeast viability was assessed by the method of methylene blue staining. The $500 \mu \mathrm{l}$ of diluted cells were added to $500 \mu \mathrm{l}$ of a methylene blue solution containing per litre: $0.25 \mathrm{~g}$ methylene blue, $1 \mathrm{~g}$ glucose, $9 \mathrm{~g} \mathrm{NaCl}, 0.42 \mathrm{~g} \mathrm{KCl}$, $0.32 \mathrm{~g} \mathrm{CaCl}_{2}$ and $0.2 \mathrm{~g} \mathrm{NaHCO}_{3}$. After $5 \mathrm{~min}$, the percentage of dead cells (appearing blue) was evaluated by counting a minimum of 300 cells on a Malassez slide.

\subsection{Medium particle size determination}

The size of the yeast cells and of the fatty acid droplets in the medium was evaluated by laser granulometry measurements, as previously described [25].

\subsection{Effect of surfactants on cell membrane integrity}

The cell membrane integrity was investigated, as proposed by Sá-Correia et al. [26], by evaluating the passive leakage of amino acids and monitoring the $260 \mathrm{~nm}$ absorbing-compounds from the cells [27]. With that aim, cells were recovered and washed with distilled water $\left(5000 \mathrm{~g}, 5 \mathrm{~min}, 4^{\circ} \mathrm{C}\right)$ until the absorbance at $260 \mathrm{~nm}\left(A_{260}\right)$ of the supernatant was inferior to 0.1 . The cells were then resuspended in $20 \mathrm{ml}$ of demineralised water, containing the tested surfactant, and incubated on a shaking table $\left(27^{\circ} \mathrm{C}, 140 \mathrm{rpm}\right)$. At convenient intervals, $1.4 \mathrm{ml}$ samples were removed and centrifuged $\left(12000 \times \mathrm{g}, 5 \mathrm{~min}, 4^{\circ} \mathrm{C}\right)$, the supernatant was then transferred to a $1 \mathrm{ml}$ cuvette and the absorbance at $260 \mathrm{~nm}\left(A_{260}\right)$ was determined.

\subsection{MATH tests}

The relative surface hydrophobicity of the cells was evaluated by microbial adhesion to hydrocarbons (MATH), namely decane. Cells taken from the biotransformation media were washed twice $(6000 \mathrm{~g}, 5 \mathrm{~min})$ and resuspended in phosphate buffer $(0.1 \mathrm{M}, \mathrm{pH} 7)$ to an $A_{600}$ of $0.70 \pm 0.02$. A $5 \mathrm{ml}$ sample of this suspension was added to a glass tube containing $1 \mathrm{ml}$ decane. The tube was gently inverted 10 times and, after $4 \mathrm{~min}, 2 \mathrm{ml}$ of the aqueous phase were removed and its $A_{600}$ was measured. The results are given in percent of bound cells $(\% \mathrm{bc})$ :

$\% \mathrm{bc}=\frac{1-A}{A_{0}}$ 


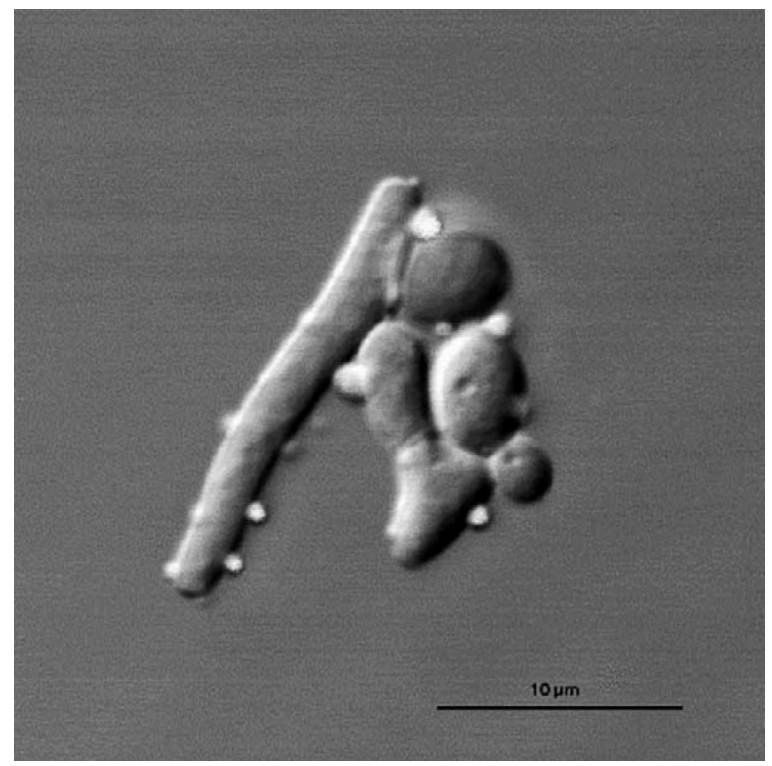

Fig. 2. Confocal microscopy observation of $Y$. lipolytica after $18 \mathrm{~h}$ of culture on methyl ricinoleate. Fatty droplets, coloured with Nile Red, are adsorbed to the surface of the cells which appear both in the yeast and mycelial forms.

where $A_{0}$ is the $A_{600}$ of the aqueous yeast suspension before mixing and $A$, after mixing.

\subsection{Confocal microscopy observations}

Yeast cells from the biotransformation medium were immobilised on a polylysine-covered slide and observed with a Leica TCS 4D Confocal Laser Scanning Microscope (CLSM; Leica, Heidelberg, Germany). The fatty droplets coloration was obtained by adding Nile Red into the biotransformation medium, at a final concentration of $8 \mathrm{mg} / \mathrm{l}$ (from a stock solution of $4 \mathrm{~g} / \mathrm{l}$ in acetone).

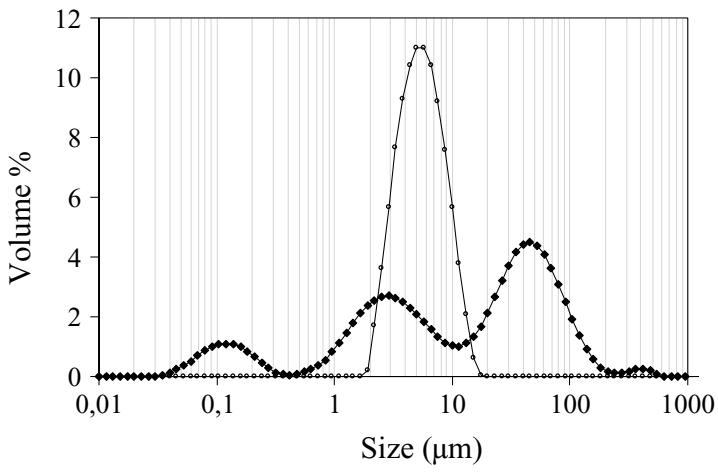

Fig. 3. Particle size distribution of the methyl ricinoleate medium without cells $(\checkmark)$ and of yeast cells alone in $0.9 \% \mathrm{NaCl}(\bigcirc)$.

\section{Results and discussion}

\subsection{Culture in biphasic media}

As shown in Fig. 2, during growth and biotransformation, contacts occurred between Y. lipolytica cells and methyl ricinoleate droplets, mainly by the adsorption of small fatty droplets on the surface of the cells. According to the granulometric measurements (Fig. 3), the methyl ricinoleate emulsion contains initially three distinct size populations. As the granulometric size distribution of the cells alone (Gaussian distribution around $5.5 \mu \mathrm{m}$ ) corresponded to what was observed using microscope, it can be assumed that the previously observed lipid droplets adhering to the surface of the cells belong mainly to the smallest detected population (around $0.15 \mu \mathrm{m}$ ) and in a lesser extent to the intermediary population $(2.8 \mu \mathrm{m})$. Such interactions were observed for the yeast and the pseudomycelial forms of $Y$. lipolytica present in the medium.

Cell-lipid contacts are very important for the utilisation of hydrophobic substrates by yeast and the intervention of

Table 1

Impact of surfactants on the interfacial area of the emulsion, on the viability of the cells and on the biotransformation of methyl ricinoleate to $\gamma$-decalactone (initial productivity and maximal concentration)

\begin{tabular}{|c|c|c|c|c|c|c|}
\hline Surfactant & HLB values & Concentration (\%) & $\begin{array}{l}\text { Interfacial } \\
\text { area }\left(\mathrm{m}^{2} / \mathrm{ml}\right)\end{array}$ & Cell viability ${ }^{\mathrm{a}}$ & $\begin{array}{l}\text { Initial productivity } \\
(\mathrm{mg} / \mathrm{l} \cdot \mathrm{h})\end{array}$ & Lactone $C_{\max }{ }^{\mathrm{b}}(\mathrm{mg} / \mathrm{l})$ \\
\hline- & & 0 & & +++ & 8.6 & $73 \pm 19$ \\
\hline \multicolumn{7}{|c|}{ Non-ionic surfactants } \\
\hline \multirow[t]{3}{*}{ Tween 80} & 15 & 0.05 & $5.7 \pm 1.1$ & +++ & 15.5 & $155 \pm 21$ \\
\hline & & 0.1 & $6.0 \pm 0.7$ & +++ & 21.7 & $234 \pm 28$ \\
\hline & & 0.2 & $6.5 \pm 0.4$ & +++ & 21.6 & $211 \pm 42$ \\
\hline \multirow[t]{2}{*}{ Triton X-100 } & 13 & 0.1 & $3.2 \pm 0.1$ & ++ & 4.9 & $78 \pm 31$ \\
\hline & & 0.2 & $3.2 \pm 0.1$ & ++ & 11.9 & $91 \pm 13$ \\
\hline \multirow[t]{2}{*}{ Saponin } & $\sim 14$ & 0.05 & $5.2 \pm 0.4$ & +++ & 16.7 & $158 \pm 24$ \\
\hline & & 0.1 & $4.7 \pm 0.1$ & +++ & 15.7 & $144 \pm 7$ \\
\hline \multicolumn{7}{|l|}{ Ionic surfactants } \\
\hline CTAB & 10 & 0.1 & & - & & \\
\hline SDS & 40 & 0.1 & & - & & \\
\hline
\end{tabular}

a +++ : viability between 90 and $100 \%,-$ : viability of about $0 \%$.

${ }^{b}$ Maximal concentration of $\gamma$-decalactone attained in the media. 


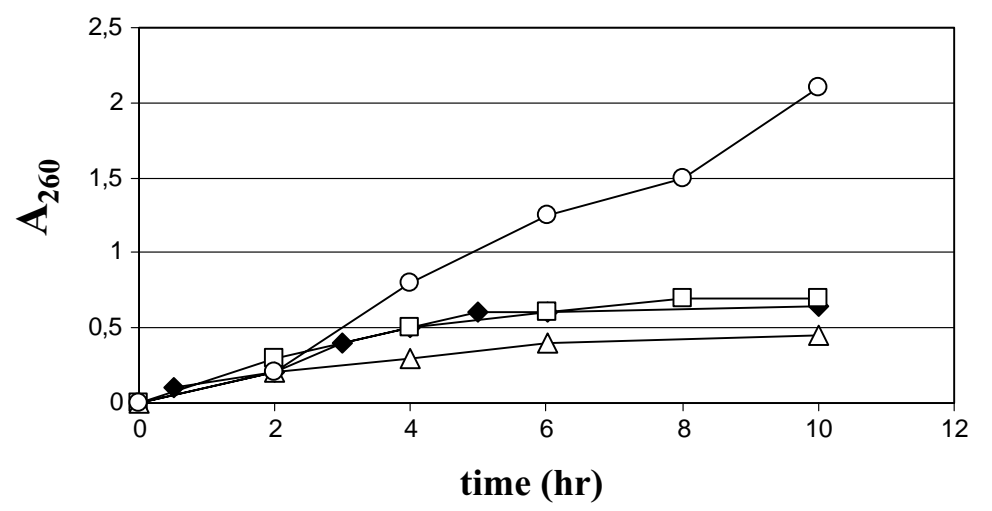

Fig. 4. Release of $260 \mathrm{~nm}$ absorbing-compounds by the cells in the presence of non-ionic surfactants: medium without surfactant ( $)$, with $0.2 \%$ Tween $80(\square), 0.1 \%$ saponin $(\triangle)$ and with $0.1 \%$ Triton $\mathrm{X}-100(\bigcirc)$.

emulsifying agents appears in many cases to be necessary to increase such interactions, we investigated thus the impact of surfactants on the biotransformation.

\subsection{Impact of several surfactants on cell viability}

Five surface-active compounds were used at various concentrations, the non-ionic Tween 80 (sorbitan polyoxyethylenmonooleate), Triton X-100 ( $t$-octylphenoxypolyethoxyethanol) and the saponin from Quillaja saponaria, cetyltrimethylammonium bromide (CTAB) which is cationic and sodium dodecyl sulphate (SDS), an anionic compound. These compounds exhibited various hydrophilic/lipophilic balance (HLB) comprised between 10 and 40 (Table 1). As determined by methylene blue staining, there was no viability in the media containing one of the ionic surfactants.

As evaluated by monitoring the $A_{260}$ of the supernatant (absorbance due to the passive diffusion of amino acids, nucleotides and nucleosides from the cells [27]), the compounds tested could influence the cell membrane permeability (Fig. 4). The release of $260 \mathrm{~nm}$ absorbing-compounds was comparable without surfactant or in the presence of Tween 80 and it slightly decreased in the presence of the saponin. However, Triton X-100 favoured the release of compounds from the cells and the $A_{260}$ value increased to
2.2 after $10 \mathrm{~h}$ compared to 0.6 without surfactant. This toxic action on yeast cells may be linked to the interaction between the surfactants and the cell membranes phospholipids and proteins. It is observed principally with the ionic surfactants: they exhibit, by the presence of their charges, a strong detergent action, denaturing the proteins [28] and, it is shown here that this action takes place independently of their HLB values.

\subsection{Impact of the surfactants on the emulsion and on biotransformation}

The interfacial area between the aqueous phase and methyl ricinoleate (with the surfactants that did not alter the yeast viability), was calculated from the droplets size that was determined by granulometry. The medium without surfactant was not taken as the reference medium for the comparison of the surface values, since the emulsion was instable. The mean interfacial surface area was comprised between $3.2 \mathrm{~m}^{2} / \mathrm{ml}$ for Triton X-100 and around $6 \mathrm{~m}^{2} / \mathrm{ml}$ for Tween 80 (Table 1). These surfaces were related to the HLB values of the surfactant. The concentration of Triton X-100 had no effect on the emulsion surface whereas there was a positive correlation between the concentration of Tween 80 and the droplet size and a negative one for saponin.

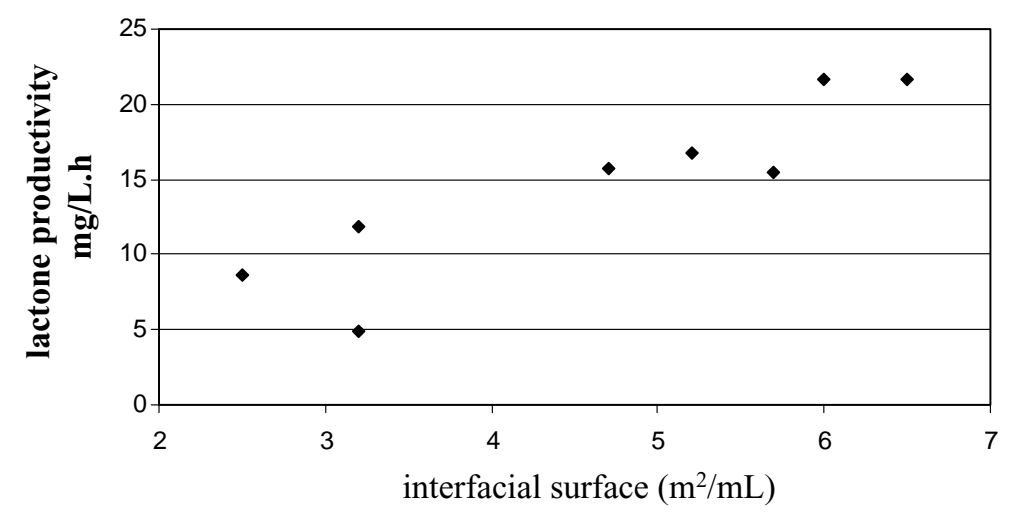

Fig. 5. Relationship between the lactone productivity and the interfacial surface area between the aqueous phase and the ricinoleate phase. 


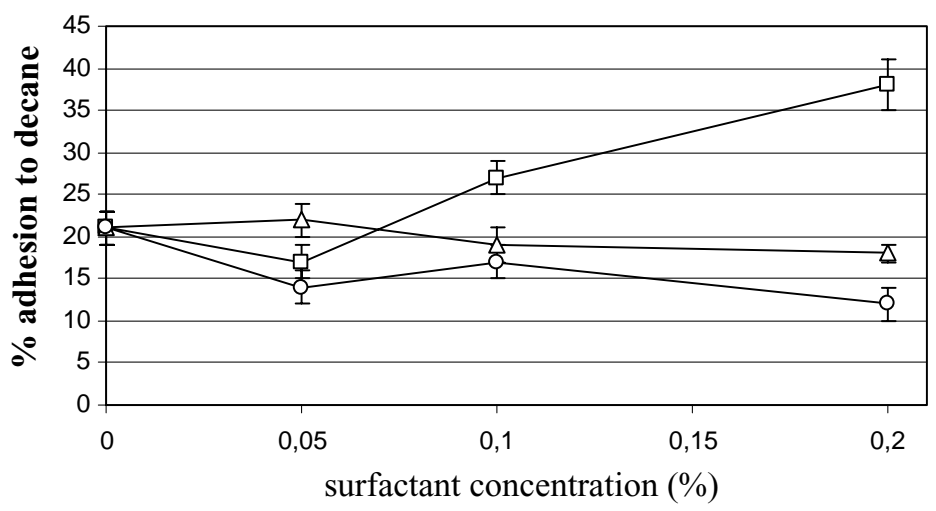

Fig. 6. Percentage of adhesion of cells to the decane phase (as evaluated by MATH tests) depending on the concentration of surfactant in the culture medium: Tween $80(\square)$, saponin $(\triangle)$ and Triton X-100 $(\bigcirc)$.

The impact of the utilisation of the different surfactants on the production of $\gamma$-decalactone is shown in Table 1. Except with $0.1 \%$ Triton X-100, the presence of surfactants always increases the maximal concentration reached in the medium. The productivity is always higher with surface-active compounds except when the yeast viability is decreased (with Triton X-100).

In Fig. 5, the relationship between $\gamma$-decalactone initial productivity and the interfacial surface area of the emulsion is presented and, interestingly, a positive correlation between these two parameters is observed. Although transfer between two phases increases with the interfacial area, this does usually not increase the microbial growth on a hydrophobic substrate that is dispersed in small globules because the droplet diameter (related to mass transfer) is more important to favour contact. An increased microbial growth was reported when fatty globules were significantly bigger or smaller than cells and a decreased growth was reported with comparable droplet sizes, since in that case the contact was more difficult $[8,29]$. In order to precise the implicated factors, the impact of surfactants on the surface properties of the yeast cells was investigated.

\subsection{Impact of the surfactants on the yeast cells surface properties}

The transfer of fatty acids from the medium to the cell involves, as the first step, the adhesion of fatty droplets to the yeast surface, which requires adequate physico-chemical properties. The yeast surface properties were compared by measuring the adhesion of the cells to decane (MATH test): this was evaluated after growth on a methyl ricinoleate medium prepared with one of the various surfactants (Fig. 6). With the saponin and with Triton X-100, the percentage of adhesion decreased with increasing concentrations of the surfactants. However, with Tween 80, the adhesion to decane increased showing a higher cell surface hydrophobicity. These data show that there is no correlation between the capacity of the cells to adhere to a hydrophobic substrate and the observed lactone productivity. This suggests that the adhesion between the yeast cells and the emulsified methyl ricinoleate is not rate-limiting in the biotransformation process. The importance of the interfacial area indicates rather that the availability of the substrate in the medium constitutes a limitation for the biotransformation of methyl ricinoleate into $\gamma$-decalactone.

\section{Conclusion}

The utilisation of microorganisms as biocatalysts in two phase systems has become of great interest in many biotechnological processes. Such bioconversion or biotransformation media are often complex, the use of surfactants has to be optimised and their role in the medium is not always understood [30,31]. The purpose of the present study was precisely to investigate the impact of the surfactants inside a biphasic biotransformation medium. It was shown that the added surfactants can have deleterious actions towards the living cells inside the medium, notably by interacting with the cell membranes. Surface-active compounds aimed at increasing the transport rate of substrate into the cell. This transport is related to the specific surface area and to the mass transfer across the cell envelope. We observe in this study that the surface area which can be modified by the presence of surfactants constitutes a key-point in the production process whereas the adhesion of small lipid droplets to the yeast cells surface (involved in the mass transfer), which can also be modified by surfactants, is not rate-limiting.

\section{Acknowledgements}

The authors are thankful to C. Bernard-Rojas and C. Humbert (CMAB) for technical help. This work was partly supported by the région Bourgogne. 


\section{References}

[1] G. Pignède, H. Wang, F. Fudalej, C. Gaillardin, M. Seman, J.-M. Nicaud, J. Bacteriol. 182 (2000) 2802.

[2] G. Pignède, H. Wang, F. Fudalej, M. Seman, C. Gaillardin, J.-M. Nicaud, Appl. Environ. Microbiol. 66 (2000) 3283.

[3] R. Margesin, F. Schinner, FEMS Microbiol. Ecol. 24 (1997) 243.

[4] C. Scioli, L. Vollaro, Wat. Res. 31 (1997) 2520.

[5] G. Barth, C. Gaillardin, FEMS Microbiol. Rev. 19 (1997) 219.

[6] Y. Waché, M. Aguedo, J.-M. Nicaud, J.-M. Belin, Appl. Microbiol. Biotechnol. 61 (2003) 393.

[7] G. Bourel, J.M. Nicaud, B. Nthangeni, J.-M. Belin, F. Husson, Enz. Microb. Technol., in press.

[8] B. Erdtsieck, K. Rietema, Anton. van Leeuw. 35 (1969) F19.

[9] A. Prokop, M. Ludvik, L.E. Erickson, Biotechnol. Bioeng. XIV (1972) 587.

[10] P. Bruheim, H. Bredholt, K. Eimhjellen, Can. J. Microbiol. 43 (1997) 17.

[11] P. Bruheim, K. Eimhjellen, Can. J. Microbiol. 44 (1998) 195.

[12] J. Li, J.L. McClements, L.A. McLandsborough, J. Food Sci. 66 (2001) 570.

[13] J.R. Gutierrez, L.E. Erickson, Biotechnol. Bioeng. XIX (1977) 1331.

[14] O. Käppeli, A. Fiechter, Biotechnol. Bioeng. 18 (1976) 967.

[15] M. Bouchez-Naïtali, D. Blanchet, V. Bardin, J.P. Vandecasteele, Microbiology 147 (2001) 2537.

[16] M.N. Meisel, G.A. Medvedeva, T.M. Kozlova, Microbiologica 45 (1976) 844.
[17] O. Käppeli, A. Fiechter, J. Bacteriol. 131 (1977) 917.

[18] S.A. Klotz, Appl. Environ. Microbiol. 55 (1989) 2119.

[19] M. Bouchez-Naïtali, H. Rakatozafy, R. Marchal, J.Y. Leveau, J.P. Vandecasteele, J. Appl. Microbiol. 86 (1999) 421.

[20] Y. Waché, M. Aguedo, J.-M. Nicaud, J.-M. Belin, Appl. Environ. Microbiol., submitted for publication.

[21] M. Aguedo, L. Beney, Y. Waché, J.-M. Belin, J. Appl. Microbiol. 94 (2003) 258.

[22] M.C. Cirigliano, G.M. Carman, Appl. Environ. Microbiol. 48 (1984) 747.

[23] M.C. Cirigliano, G.M. Carman, Appl. Environ. Microbiol. 50 (1985) 846.

[24] Y. Waché, K. Bergmark, J.-L. Courthaudon, M. Aguedo, J.-M. Nicaud, J.-M. Belin, Lett. Appl. Microbiol. 30 (2000) 183.

[25] M. Aguedo, Y. Waché, V. Mazoyer, A. Sequeira-LeGrand, J.-M. Belin, J. Agric. Food Chem. 51 (2003) 3007.

[26] I. Sá-correia, S.P. Salgueiro, C.A. Viegas, J.M. Novais, Yeast 5 (1989) S123.

[27] T.C. Lee, M.J. Lewis, J. Food Sci. 33 (1968) 124.

[28] R.E. Glover, R.R. Smith, M.V. Jones, S.K. Jackson, C.C. Rowlands, FEMS Microbiol. Lett. 177 (1999) 57.

[29] E. Bakhuis, P. Bos, Anton. van Leeuw. 35 (1969) F47.

[30] A. Cruz, P. Fernandes, J.M.S. Cabral, H.M. Pinheiro, J. Mol. Catal. B 11 (2001) 579.

[31] A. Cruz, P. Fernandes, J.M.S. Cabral, H.M. Pinheiro, J. Mol. Catal. B 19-20 (2002) 371. 